\title{
Disarmament and Development: An African View
}

\author{
Eboe Hutchful
}

In the past decade the African continent has been riven by armed conflict. The record is familiar and will be reviewed only briefly here: liberation wars have been fought and concluded in Mozambique, GuineaBissau, Angola, and Zimbabwe. Similar wars are in progress in the Western Sahara, Namibia, and Azania (South Africa). Civil wars are currently under way in Ethiopia and Chad, in both cases of long duration, and with no immediate end in sight, in spite of substantial foreign involvement. 'National' wars were fought in 1977 and 1978 between Ethiopia and Somalia on one hand and Uganda and Tanzania on the other, in the one case over disputed border territory and in the other to unseat a regime. Both again involved foreign intervention, but in different forms and to greatly varying degrees.

Foreign intervention of various kinds has become a more and more general feature of these wars, in some cases involving actual combat by foreign troops, and in a number of instances repeated interventions by the same powers. France has a particularly long record of such interventions - in Chad (several times), Shaba (twice), and the Central African Republic, also previously in the Cameroon, Senegal, and Gabon. The Soviet Union and Cuba have also intervened in Angola and Ethiopia. The United States has intervened more covertly in Angola, Chad, Sudan, Morocco and Egypt. If forcible intrusion by external powers has been common, so has intervention by regional 'powers' (South Africa in Angola since 1975, with repeated incursions into other 'frontline' states; Morocco and Senegal in Shaba; Libya in Chad since 1973 and more overtly since 1980; 'OAU forces' in Chad in 1981; and Senegal in the Gambia in 1981, etc.). Foreign troops are garrisoned on African soil in several countries (the French in Senegal, the Ivory Coast, Central African Republic and Djibouti, Cubans in Angola and Ethiopia) and over the period under review several African states offered bases on their soil for the use of foreign military forces. Both foreign and regional African powers have established or contemplated unilateral or mutual intervention forces of which the French Forces d'Action Rapide and the US Rapid Deployment Force (RDF) now renamed Central Command (US CENTCOM) are th: best known.

Finally there is the deepening tendency toward coup d'états and militarisation of the state apparatus in Africa. At the end of 1984 no less than half of the 50 states in Africa were under military rule. The distinction between military and civil government had in any case become academic. Most of the civilian governments left in power rule on the basis of their security forces and are in practice no less repressive.

Not surprisingly these developments have been accompanied by rapid growth in military budgets and in the scale and sophistication of arms transfers. ${ }^{1}$ This is particularly true of the North African countries (Libya, Algeria, Egypt, Morocco and Tunisia), the oil exporters (especially Libya, Algeria, and Nigeria), and South Africa, although there were significant increases in individual sub-Saharan African countries as well. The bulk of the heavy armaments transferred to Africa also went to North Africa, South Africa, and Ethiopia.

Given this background Africa could well be considered the most war-torn continent of the last decade. This is particularly true of the period 1975 to 1980. What do these developments portend, and how might they be explained? What are the prospects for continental disarmament and arms control? Is militarisation the main problem? How does the process of militarisation articulate, for instance, with the serious economic crisis in which Africa finds itself? A number of preliminary considerations may help to clarify the issues. The first is that the process of

\footnotetext{
1 For more detailed analysis see Robin Luckham. 'Militarisation in Africa', in World Aimaments and Disarmament: SIPRI Yearbook 1985. Taylor and Francis for the Stockholm International Peace Research Institute. London. 1985, and also L. E. Hutchful. 'Trends in Africa', Altomatives, vol 10 no 1. March 1984
} 
militarisation (viewed in terms of increased military spending and arms acquisition) has proceeded far from evenly over the continent as a whole. The strongest tendencies toward military build-up have occurred among oil-producing countries, and among the countries of North Africa, the Horn and Southern Africa, particularly South Africa. These are either countries located close to a zone of endemic war (the Middle East) or actually involved in war (South Africa, the Horn, Morocco in the Sahara), or commanding the surpluses to finance large-scale arms purchases (the oil producers), or both (the North African oil-exporters). On the other hand the military build-up has been much less pronounced among the remaining African states, who const itute the majority. In a number of cases in this last group the level of military expenditure (expressed in constant dollars) has actually declined, largely in response to the current recession. The oil-exporting countries (including Libya, Algeria, Nigeria, Gabon, Congo and Cameroon but excluding Angola) accounted for almost 50 per cent and 20 per cent respectively of the total arms bill of the oil exporters. Among the oil importing North African countries Egypt is the largest single purchaser, accounting for between 50 and 58 per cent of total African arms supplies from the 1960 s until 1974, when her purchases were outstripped by those of Libya and Algeria. However, in 1982 and 1983 Egypt, Morocco, and Tunisia again accounted for no less than 58 per cent of all major African arms imports. This situation has evolved as a result of the new strategic relationship recently constructed between the United States, Egypt and Morocco.

These regional variations mean it is difficult to make valid generalisations for Africa as a whole. Currently the continent is divided into a small group of relatively well-armed countries (South Africa, Egypt, Libya, Algeria, Morocco, Ethiopia, and Nigeria) and a much larger group of countries whose military forces and armaments levels are no more than adequate for purposes of legitimate territorial defence (in many cases less than adequate). Of the countries in the first group only Ethiopia and Nigeria are located in black Africa, while with the exception of South Africa all others are in North Africa. A second consideration is that the accelerated acquisition of armaments over the period in question was largely the result of a specific but probably temporary conjuncture - in particular the uncompleted agenda of national liberation and windfall oil surpluses - which provided both the necessity and the opportunity to acquire arms on an unusually large scale. With changes in this conjuncture (drastic falls in oil revenue, scaling down of some wars, etc.) there has been a sharp decline in overall arms transfers, particularly to oil-producers and Black Africa.
In any case the absolute limits to this process of militarisation should be stressed. In terms of certain indices (such as volume of military spending and number of soldiers in relation to population) Africa remains one of the less militarised continents. In 1978, at the peak of the military build-up, Africa accounted for 25 per cent of total Third World arms imports, but only 6.5 per cent of all Third World military expenditures, and 1.5 per cent of total world military expenditures. It could be argued plausibly that, on the contrary, it is precisely the low military means of African states that is the cause of certain types of military hostilities, such as foreign and South African armed interventions. Thus defining 'armamentism' as the core problem merely leads to endless confusion about cause and effect. What is impressive and worth analysing is the fact that at the same time as Africa as a whole ranks low in the volume and technical sophistication of armaments, the continent ranks high in the frequency of war, coups and foreign incursions, as well as in the level of domestic repression, abuse of human rights, and displaced populations (refugees) - conditions synonymous with rampant militarism. A low capacity for acquiring and absorbing armaments has not prevented these tendencies from developing; in most of these respects there is little difference between the least and the most hẹavily armed countries in Africa. This suggests the need to shift the focus of analysis from arms as such to some understanding of the social and material conditions underlying this generalisation of violence and repression.

Another justification for this shift in focus is that the regional variations in militarisation noted above in fact obscure certain obvious similarities in the structures and historical experiences of African societies. Indeed these apparent variations represent more than different facets (unevenly developed as between countries and regions) of the common structures and experiences of these countries. It can be argued that the rampant militarisation of life and society in Africa expresses in many ways the typical trajectory of development of the peripheral social formations at the present stage of imperialism. This stage is characterised by (a) the internationalisation of capital in its monopoly form, as productive capital (the so-called 'new international division of labour'); (b) profound shifts in the balance of power and of class forces on the world scene, between on the one hand imperialism and national liberation, and on the other between capitalism and socialism; (c) the multilateralisation of imperialism, and finally (d) a generalised crisis in world capitalism. What we are seeing in Africa, to a large extent, are the effects of certain fundamental political and economic changes underlying this conjuncture which have had far- 
reaching implications for the strategic balance in Africa and for the stability of its social formations.

In the first instance, these formations are all defined by their colonial origin. Colonialism left them with particularly complex contradictions, reflected in their fragmentation on racial, class, communal and cultural/religious lines, and in their inability to constitute coherent social relations. These contradictions arose principally from the essentially racist culture and primitive capitalism of colonial society. The penetration of capitalism simultaneously dissolved previous modes of production and abolished the traditional self-sufficiency of the lineage economy; and on the other hand implanted a new social division of labour based on the commoditisation of labour and the privatisation of the social means of production. The creation of entirely arbitrary frontiers corresponding to the economic and strategic interests of foreign powers permanently divided many nationalities and placed them under different colonial administrations, at the same time abolishing their previous autonomy and subjecting them forcibly to a centralised state authority. These transformations in the body of African society were responsible not only for new forms of racial and class struggles but also for the conflicts between nationalities and cultures. The 'tribalism' and 'nationalities question' so central to African politics often constituted in reality either forms of resistance to this reconstitution of the previous conditions of communal life, or covert vehicles of class struggle.

The nature of the colonial experience accounts for the two most common forms of war in Africa. First, wars of liberation, which became from the early 1970 s on the typical mode of decolonisation, as opposed to the consensual decolonisations of the 1950s and 1960s. The victory of the liberation wars created (especially in Southern Africa) far-reaching changes in the regional, and potentially global, balance of power and exerted considerable strategic influence on the Indian Ocean and Middle East. In a number of cases (Angola, Zimbabwe, possibly Namibia) these wars were overlaid by ideological and ethnic divisions among the liberation forces themselves. Second, wars of seccession or civil wars (Ethiopia, Chad, Sudan, previously Nigeria and Zaire, and lesser examples), and 'border' wars (Somalia vs. Ethiopia). Although these originate typically as internal wars, various factors (ideological issues, the strategic location of the battleground, etc.) invite foreign involvement. Foreign participation is almost invariably a feature of both types of war, and may prove decisive in determining their outcome, or, at the very least, increase their duration and intensity. Foreign participation is stimulated by the coincidence of the objectives of one or other of the regional combatants with the strategic objectives of an external power. In most instances involving the NATO powers, it is stimulated by the desire to protect client regimes. This latter type of intervention is associated with the erosion of the NATO hegemony in Africa by liberation wars and the growing fragility of client regimes in political and economic difficulties. This is particularly true of recent US and French interventions. Given the dependent character of African societies, and the high level of influence retained in them by the foreign bourgeoisies, such participation (which differs only in form and degree from other means by which these bourgeoisies make their influence felt) cannot properly be considered as 'external'. On the contrary, such interventions constitute a 'normal' aspect of their politics.

A second result of the colonial experience consists in the fact that these countries attained independence with a certain pathology entrenched in their economic structures. But this alone provides little understanding of what has subsequently happened in these countries. African countries, with few exceptions, have been characterised since independence by a particular ideology and broad strategy of development. This ideology conceptualised 'development' in terms of capitalist industrialisation, emphasised the primacy of foreign capital as the 'engine' of a process of growth oriented toward the world market. This developmental ideology did not arise uniquely from the African economies but was partly the product of fundamental changes in world capitalism associated with the postwar imperialist conjuncture mentioned above, and which already involved substantial modification of the international division of labour. This modification entailed a measure of industrial relocation and the initiation of semi-manufacturing activities in peripheral countries under the financial and technological control of multinational companies (MNCs), accompanied simultaneously by the fragmentation of the labour process on a global scale. It also involved a new role for banks and international financial agencies in the financing of Third World 'development'. The financial activities of the banks reached particularly high levels with the emergence of OPEC oil surpluses and the Eurocurrency market. Peripheral industrialisation was in the interest of the foreign monopolies, given not only the high volume of business created for the banks and credit agencies, but also the monopolistic privileges, tariff protection, tax and investment concessions, and repressive labour regimes available to the industrial corporations in a period when high wages, falling profit margins, and sharp international competition was the rule. The MNCs, by fragmenting previously integrated production processes across widely separated geographical regions and reintegrating them exclusively within their worldwide organisational structures, were able to effect 
maximal export of 'profits' and to minimise national control. The problem was not exclusively at the micro level: the emphasis on foreign capital as the primary condition for the technological advancement of productive forces in the peripheral countries required that the labour process in these countries be subordinated to the self-valorisation of foreign capital, and that their economic expansion be conditional on the expanded reproduction of the metropolitan economies.

Two observations are relevant here about this form of development. The first regards the greatly enhanced role of the state and of the political domain in this process. The process of capitalist transformation (under whatever name it is disguised) requires as a precondition a revolution in social and economic relations and attitudes. This entails the uprooting of archaic forms, the smashing or reconstitution of social relations and practices that constitute barriers to the penetration and valorisation of capital, and so on. In this process the state, in addition to its direct intervention in production, plays an unusually prominent role. This same process necessarily involves various degrees of social dislocation and conflict and provokes resistance, often clothed in the inchoate language of traditionalism, communal 'rights' or religious fundamentalism. As in the colonial period these transformations, associated with the 'march of progress', are directly or indirectly responsible for the prevalence of the communal, regional, and religious antagonisms that underlie African militarisation (the more so as the post-colonial state itself, in addition to its class character, is often perceived to have a 'partisan' ethnic, regional, or religious identity). This situation is also responsible for the tendency of African states to define their role primarily in terms of the establishment of a new social and structural equilibrium and the arbitration of contending social interests ('national integration').

Secondly, this form of development, in combination with certain internal factors, has left Africa particularly vulnerable to the global capitalist crisis. This developmental strategy, oriented toward the world market, has been characterised by the export of multiplier effects (profits, jobs, R \& D, etc.) and by the fact that the bulk of value is retained either within the networks of the MNCs or recycled in the servicing of external loans and credits. For this reason little 'development' has taken place on African soil. Given their particular location in the 'new' international division of labour, and their role in keeping up the general rate of profit for international capital, the African countries (like other underdeveloped economies) tend to reproduce in an exaggerated way the periodic crises of the world market. This has been apparent in Africa since the mid-1960s. In the last decade however, this crisis has become particularly acute, and manifests itself in debt-peonage, industrial and agricultural collapse, and the threat of mass starvation. Much of the responsibility for this crisis must be located within the continent itself, in adverse natural and ecological conditions, and perhaps even more in colossal waste and mismanagement by African leaders. Nevertheless it is equally clear that this crisis is part of the generalised crisis of capitalism. In the advanced capitalist countries this crisis, and the reorganisation of the social conditions of production necessary to mediate it, entail increasingly anarchic and crisis-ridden conditions, with the worst recession in a half-century, the failure of traditional (Keynesian) anti-recessionary policies, and the emergence of conservative monetarist governments in the key capitalist countries. Militarism is a prominent aspect of the international posture of such regimes, a fact already apparent in their African policies.

In Africa the appearance (or reflection) of this crisis coincided with the emergence, first in individual countries in the 1960s, and then increasingly on a continental scale, of repressive and authoritarian regimes of 'austerity'. Economic retrogression, approaching the dimensions of disaster in many countries, has been worsened by war in some situations and in turn stimulates war. Although accurate statistics are lacking, it can be assumed that for every person displaced by war, several more are displaced by drought and economic decline.

However, the authoritarian military and civil regimes which have now become the standard political form in Africa do not emerge simply to hold together these fragmented and crisis-ridden formations. On the contrary they constitute - and this has become particularly clear since 1980 - the necessary condition for the particular mode of "crisis management' which is taking place on the continent under the superintendence of the international financial agencies (the IMF and the World Bank). This process is informed less by concern for the material well-being of the African masses than by the interests of the corporate and banking monopolies and the strategic objectives of the NATO powers. Its instruments are a set of brutal 'austerity' measures (large-scale retrenchment of workers, severe cutbacks in educational, health and social welfare spending, etc.) which fall predominantly on the shoulders of the poor, and which in many ways exacerbate the crisis. Consequently these 'adjustment programs' require as their vehicle regimes with considerable actual or potential repressive capability (this is already quite obvious in Latin America, but the recent coups in the Sudan, Ghana and Nigeria point in similar directions). The irony is that many of the funds 'saved' on welfare and other forms of spending on the poor are eventually 
diverted into arms, which become necessary to repress the resulting social contradictions. Between 1978 and 1982 at least 26 African countries entered into some form of 'understanding' with the IMF, on terms which were, according to the IMF itself, more onerous than any previously imposed. Thus at the precise moment of their increasing militarisation and repressiveness, African states retain less 'sovereignty' than at any time since independence.

It is clear that for most of Africa - the apparent proliferation of arms conflicts notwithstanding - the real 'wars' are their struggles against their repressive conditions of existence. It is at this level that the "peace question' should first be posed. The fundamental problem is the quality of material life and of social relations, and the availability of means for advancing this quality (or at least preventing its retrogression!) and resolving conflicts peacefully. The militarist option dominant in Africa indicates both the acuteness of the contradictions and the limited means for their mediation; it is not a product simply of the availability of arms per se.

From this point of view there is a good deal wrong with the conventional way of posing the 'peace' and 'disarmament' question. First of all there is exclusive stress - consistent with the interests of the world powers - on nuclearisation, and very little (except in a manipulative sense) on exploitation, repression and abuse of real human rights, as the threat to 'peace'. This 'concern' (like the concern over apartheid) is easily appropriated by even the most repressive and militarist regimes in Africa, and everybody is able to take a 'progressive' position on this question. Secondly, the 'nuclearisation' versus 'peace' formula robs the concept of peace of any immediate, social content. In Africa the immediate threat to peace lies in those conditions which are bringing the continent to the verge of barbarism. Fear of nuclear war runs a poor second to more immediate, mundane fears about job security, the threat of starvation, disease, anxiety over the most basic necessities of life - fears more debilitating than any provoked by nuclear weaponry. There was an incident recently that is worth quoting in this context. On May Day in Lagos this year Nigerian workers grumbled and booed when the SecretaryGeneral of the Nigerian Labour Congress commenced his traditional May Day address with a condemnation of the nuclear 'arms race'. Commenting on the incident, a leading national daily observed that the Secretary-General had demonstrated the "wrong order of priorities' in talking about issues that Nigerian workers (faced with mass retrenchment) did not at that moment 'care to think about' (National Concord, Lagos, May 3).

Nor were the Nigerian workers necessarily acting irresponsibly. The nuclear monopoly consigns the future of disarmament and the negotiating process to a small coterie of world powers and leaders, marginalising the voices of the vast majority of humanity, even within the nuclearised countries. Even more important, the focus on nuclearisation has a clear ideological function, and that is precisely to push the argument for qualitative transformation from the agenda. The fright generated by repeated warnings of the probability of nuclear war and even the possibility or imminence of 'limited nuclear war' predisposes people to accept 'peace' at any price. The question of transformation of the existing framework of social and global relations is relegated to the background. This motive is not absent from the thinking of successive American administrations, the present one in particular. Conversely, every revolutionary struggle for justice and change is branded as a threat to 'peace'. Naturally this conception of 'peace' and what constitutes 'threats' to it has served to discredit thoroughly the idea of peace itself.

Finally there is a real possibility that disarmament negotiations may be used to forestall changes in the global and regional balance of power through the strategy of 'linkage', which ties progress on disarmament to progress on regional questions in Africa and elsewhere. This is a position advanced by the Americans, and was a major factor in the nonratification of SALT II. In this case progress in disarmament can only take place at the expense of national liberation. Similarly with the doctrine of 'equal security' enshrined as a basis for these negotiations: although a plausible principle on which to base mutual negotiations, its political implications are quite profound. For America and the NATO powers 'security' has to include as a condition the maintenance of the present international division of labour and continued access to the resources and markets of other countries, i.e. the preservation of free trade regimes and resistance to local sovereignty over resources - precisely the structures which many Third World countries wish to change. And indeed questions of 'economic security' have received increasing emphasis in the NATO definition of 'equal security', largely as a result of regional developments in Africa and the Middle East. This conception of 'security', once adopted, leads logically not only to 'linkage' but also to RDF/ USCENTCOM-style interventionalism.

It is not clear that 'disarmament' is rendered any more meaningful by shifting it from the focus on nuclearisation and tying it to the problematic of development. Here arms spending is seen as standing in opposition to 'productive' socioeconomic investment. The assumption is that reduced arms spending by the major powers as well as the underdeveloped countries can be expected to release more funds for 
development expenditure. Naturally the vast (and growing) gap between arms spending and development aid transfers must offend any sense of decency. There is something positively obscene about cutting the income of aged pensioners, or eliminating lunches for low-income schoolchildren, in order to finance the acquisition of even better weapons of destruction, as is currently happening in the leading capitalist countries. Nevertheless there are a number of problems with the 'arms versus development' formula. The first is empirical: there is no evidence that resources released from cutbacks in arms spending would necessarily go into development spending, rather than, say, other forms of 'waste' or unproductive spending.

At the same time the argument either ignores the presumed growth effects of arms spending in the large arms-producing countries, or rejects arms spending as being less 'growth generating' than alternative investment in other, directly productive areas. Under capitalism however the question is not growth but the kind of growth that results in the maximisation of the rate of profit. This objective may be better achieved by 'wasteful' investments in armaments than in sat isfying basic human needs. These considerations are already shaping the reception in the NATO countries of President Reagan's 'Strategic Defence Initiative' ('Star Wars'). In spite of the official 'hedging' of governments, Western corporations are already queueing up for contracts from the $\$ 26$ bn budget, and there are fears that the spin-offs from this research funding may increase the technological gap between Europe and America unless there is European participation. The concern for profit and market competitiveness, rather than pious condemnation of the militarisation of space, ultimately will decide the European reaction.

Admittedly the same considerations do not appear to apply in those underdeveloped countries where arms procurement does not generate similar multiplier effects. However even in such cases arms procurement may not always entail proportionate economic costs, since it may be financed largely by outright or partial grants and soft credits and reflect the strategic interests of one or other superpower. This allows countries like Egypt, Morocco or Ethiopia to maintain what appear to be disproportionately large military establishments.

The second, more fundamental problem with the 'disarmament vs. development' formula is ideological. This consists in its idealism and lack of understanding of the social utility of force, that is of the existence of material contradictions that condition armament, and hence of the fact that the latter may be necessary for the reproduction of certain structures and relationships at either the domestic or global level, or both.
This is the case with the imperialist hegemony, which can only be maintained, at this juncture, by global (or globalised) systems of violence. It could be argued that contemporary peripheral conditions of accumulation, and the crises associated with them, necessitate precisely such outlays on force, and that whether or not the outlays are 'excessive' is a secondary matter. This outlay could also be argued to be a condition for military social dominance, which, far from being a form of political deviance, appears on the contrary, to be a necessary aspect of the morphology of contemporary underdevelopment. Thus instead of counterposing (in a utopian manner) 'arms' and 'development', we need rather to investigate the objective relation between certain forms of development and arms - or, more properly stated, between development and repressive and militaristic policies. The relationship between development and arma ment may then be reformulated, analytically, in terms of the struggle to establish or sustain the political preconditions for a particular form of 'development'. The process of 'development' is not politically neutral. It always involves a struggle between socialism and capitalism, the form of development in a particular country is the product of a definite correlation, not only of domestic, but also of international class forces. In this sense both the high level of domestic political violence and the active participation of external forces are fundamental to the process of development in the Third World countries, rather than extraneous or in opposition to it.

\section{Postscript: the Possibility of an African 'Nuclear Free Zone'}

In spite of the foregoing, a good case can be made for declaring and enforcing a 'nuclear free zone' (NFZ) in Africa. Such proposals have been made several times by African leaders since the 1960 s. There have been similar proposals for NFZs in the Middle East, the Mediterranean, Latin America, and Northern Europe. But the African case appears particularly strong, partly because of the relatively low level of military sophistication on the continent, the absence of vital strategic targets, and the fact that until 1979, few if any African countries appeared capable of the technology required for the production of nuclear weaponry. In spite of this it is far from clear that a NFZ in Africa is feasible or relevant. In the first place 'Star Wars' proposals, if allowed to proceed (as seems certain), will render the concept of a NFZ largely useless. Secondly, NFZ schemes, although excellent in theory, have a poor record of actual implementation. Before the recent unilateral declaration of a NFZ by Iceland, the only example of a NFZ was the Tlatelolco agreement of 1967 between Latin American countries which banned the presence of nuclear weapons on the territory of the participating states (although it did not 
prohibit transhipment or include all the countries on the continent). Thirdly, in the case of Africa, the nuclearisation of the neighbouring Indian Ocean is already a distinct possibility. In recent years there has been a substantial naval build-up in the Indian Ocean by the United States and the Soviet Union, with surface and submarine vessels permanently stationed in the region. Although neither power discloses which of its vessels carry nuclear weaponry, it is only realistic to expect the presence of some form of nuclear weaponry on board vessels belonging to both sides. On the Indian subcontinent a nuclear arms race between India and Pakistan also appears inevitable. Even on the African continent itself the possibility of a NFZ may already have been foreclosed by the almost certain development of a nuclear capability by South Africa. This has led in turn to demands that Nigeria, for instance, should 'go nuclear' to counter the South African threat, although it is not certain how seriously such demands should be taken.

In any case any NFZ can be established only with the agreement and collaboration of the superpowers and enforced by those powers. The policy of restraint that this requires cannot be discerned in the present international atmosphere. African countries themselves have no effective means of enforcing a NFZ. On the contrary the economic and military weakness of African countries may render them particularly vulnerable to various forms of nuclear blackmail (such as secret stationing or transhipment of nuclear weapons in violation of NFZ provisions), in principle no different from the external manipulations that have characterised the proposals for 'mutual security' arrangements, etc. There have been persistent and disturbing rumours of African governments contemplating secret agreements that would permit the dumping of nuclear wastes off their continental shelf in return for large payments, and in one case an African government (Zaire) actually allowed the testing on its soil of rocketry with potential nuclear application.

\section{Conclusion}

The case for disarmament has not been established in Africa. This is due to the emphasis on arms control rather than on solutions to the systemic contradictions which produce violence. It is assumed that once a correct-negotiating formula has been found and agreement reached on limitation of arms, wars will be minimised or eradicated. The situation in Africa shows that there is in fact no inconsistency between a relatively low level of armaments and a high level of war and political violence. On the other hand it is surprising how infrequently official 'disarmament' and 'arms control' advocates address the underlying problems - of class oppression, injustice and deprivation - responsible for violence in Africa. A second misconception is in the tendency to oppose 'militarism' (and in particular military spending) and 'development', without attempting to analyse their social relation. These conventional positions have rendered largely irrelevant (if not entirely discredited) disarmament and the 'peace' campaign as far as Africa is concerned. Before one can address successfully the problem of war and arms in Africa (and elsewhere), one must first address the problem of justice. 